doi: $10.26529 /$ cepsj.299

\title{
Drawings as External Representations of Children's Fundamental Ideas and the Emotional Atmosphere in Geometry Lessons
}

Dubravka Glasnović Gracin ${ }^{\star 1}$ And Ana Kuzle ${ }^{2}$

$\approx$ The important role that geometry plays in the mathematics curriculum has been extensively documented. However, the reduction of geometry in school mathematics, and the focus on basic computation and procedures, raises the question of the competencies students acquire and the classroom atmosphere in geometry lessons. The goal of this multiple case study was to analyse four students' conceptions of geometry and the emotional atmosphere in geometry lessons on an individual level. Drawings were used as external representations of the students' geometrical ideas and the emotional atmosphere. The results show that the participants have a narrow understanding of geometry, and that geometry teaching in their classrooms is reduced to frontal teaching with very limited communication. Nevertheless, the emotional atmosphere in these four cases could be described as positive or ambivalent. Based on the data, the results are discussed not only with regard to the utility of drawings as a research method to gain insights into students' conceptions of geometry and emotional atmosphere in geometry lessons, but also with regard to their theoretical and practical implications.

Keywords: drawings, emotional atmosphere, external representations, fundamental ideas, geometry

$1{ }^{\star}$ Corresponding Author. University of Zagreb, Faculty of Teacher Education, Croatia; dubravka.glasnovic@ufzg.hr.

2 University of Potsdam, Faculty of Human Sciences, Germany. 


\section{Risanje v vlogi reprezentacij učenčevih temeljnih geometrijskih pojmov in prikazovanje doživljanja pouka geometrije}

Dubravka Glasnović Gracin in Ana Kuzle

$\approx$ Poznano je, da ima geometrija v matematičnem kurikulumu pomembno vlogo. Po drugi strani pa je geometriji namenjenih bistveno manj ur $\mathrm{v}$ šolski matematiki v primerjavi $\mathrm{z}$ aritmetiko, pri kateri je ključno poznavanje postopkov računanja, zato se upravičeno postavlja vprašanje, $\mathrm{v}$ kolikšni meri učenci dosežejo cilje pri pouku geometrije in kako pouk doživljajo. Cilj naše študije štirih primerov je bil analizirati, kako učenci razumejo idejo temeljnih pojmov $\mathrm{v}$ geometriji in kako reprezentirajo doživljanje pouka geometrije. Učence smo spodbudili, da so oboje prikazali z risanjem oz. z grafično zunanjo reprezentacijo. Rezultati kažejo, da imajo učenci ozko razumevanje ključnih pojmov v geometriji in da je poučevanje razredih učencev, ki smo jih preučevali, omejeno na frontalno obliko z zelo omejeno komunikacijo. Ne glede na to bi lahko pri vseh primerih, ki smo jih preučevali, sklenili, da učenci doživljajo pouk geometrije pozitivno ali ambivalentno. Učenčeve grafične reprezentacije smo analizirali $\mathrm{z}$ vidika vpogleda $\mathrm{v}$ učenčevo razumevanje izbranih geometrijskih pojmov ter doživljanja pouka geometrije pa tudi z vidika njihovih teoretičnih in praktičnih implikacij za pouk matematike.

Ključne besede: grafične reprezentacije, doživljanje pouka, zunanje reprezentacije, temeljni pojmi, geometrija 


\section{Introduction}

In the past several decades, the overall amount of geometry in many national curricula has been reduced (Mammana \& Villani, 1998) due to a desire to increase the coverage of other mathematical disciplines in school mathematics, such as numeracy and statistics (Jones, 2000). These findings raise certain questions regarding current geometry education: What meanings do students assign to geometry? What geometrical concepts do they learn? What attitudes do they have towards geometry? Or more generally, what do geometry lessons look like today through the eyes of students?

Interest in classroom activities and what is happening during lessons has many different components. Apart from mathematical dimensions, it encompasses grasping the social and emotional climate, which may influence parameters such as enhanced academic achievement, constructive learning processes and reduced emotional problems (Hannula, 2011). Recent research (e.g., Laine, Ahtee, Näveri, Pehkonen, Portaankorva-Koivisto, \& Tuohilampi, 2015; Pehkonen, Ahtee, Tikkanen, \& Laine, 2011) has shown that the use of drawings as external representations provides a multidimensional and a holistic view of students' latent experiences in the mathematics classroom. With these considerations in mind, the aim of the present multiple case study was to obtain insights into primary grade students' individual conceptions of geometry and into the emotional atmosphere in geometry lessons on an individual level through the lens of students by using external representations, namely drawings.

\section{Theoretical Background}

\section{Fundamental ideas in geometry}

Geometry has traditionally been one of the important areas of mathematics education throughout the world. It provides experiences that help students develop an understanding of forms and their properties, enabling them to solve relevant problems and to apply geometric properties to real-world situations (Jones, 2000).

One trend focuses on the construction of the geometry curriculum organised around fundamental ideas, a term that can be interpreted in many different ways. Winter (1976) defined fundamental ideas as ideas that have strong references to reality and can be used to create different aspects and approaches. In addition, they are characterised by a high degree of inner richness of relationships, and by gradual and continuous development in every grade. Wittmann 
(1999) proposed that school geometry be organised around the following seven fundamental ideas: (1) geometric forms and their construction, (2) operations with forms, (3) coordinates, (4) measurement, (5) geometric patterns, (6) forms in the environment, and (7) geometrisation. (1) The structural framework of elementary geometric forms is three-dimensional space, which is populated by forms of different dimensions: o-dimensional points, 1-dimensional lines, 2-dimensional surfaces and 3-dimensional solids. Geometric shapes can be constructed or produced in a variety of ways (e.g., drawing tools, material) through which their characteristics are imprinted. (2) Geometric forms can be operated on; they can be shifted (e.g., translation, rotation, mirroring), reduced/ increased, projected onto a plane, shear, compressed/extended in a certain direction, distorted, split into parts, combined with other figures and shapes to form more complex figures and shapes, and superimposed. (3) Coordinate systems can be introduced on lines, surfaces and in space to describe the position of points with the help of coordinates. (4) According to given units of measure, the length, area and volume of geometric forms can be measured. Angle measurement, angle calculation, formulae for perimeter, area and volume and trigonometric formulas also deal with measurement. (5) In geometry, there are many possibilities to relate points, lines, surfaces, bodies and their dimensions in such a way that geometric patterns emerge (e.g., frieze patterns). (6) Real objects, operations on and with them as well as relations between them can be described with the help of geometric forms. (7) Plane and spatial geometric facts, properties and problems, but also a plethora of relationships and abstract relationships between numbers (e.g., triangular numbers), can be translated into the language of geometry and described geometrically (geometrisation), and then translated again into practical solutions.

Wittmann's (1999) fundamental ideas are aligned with ICME study recommendations for new geometry curricula (Mammana \& Villani, 1998), and have been adopted by many national curricula. In the Croatian curriculum (MZOS, 2006), for instance, five of the seven fundamental ideas ${ }^{3}$ are present. Thus, the Croatian curriculum reflects the multi-dimensional view of geometry, although the extent of this focus differs. However, the question of the influence this may have on the meanings students assign to geometry, and whether and to what degree they recognise this multi-dimensionality of geometry, remains open.

3 Geometric patterns and geometrisation as fundamental ideas are not explicitly stated in the current Croatian mathematics curriculum (MZOS, 2006). 


\section{The emotional atmosphere in a classroom}

žIn the last few decades, there has been increasing interest in research on affect. This has involved various foci, such as the role of affect in learning and in the social context of the classroom, and the role of emotions in mathematical thinking (Hannula, 2011; Philipp, 2007). Philipp (2007) defined emotions as "feelings or states of consciousness, distinguished from cognition. Emotions change more rapidly and are felt more intensely than attitudes and beliefs" (p. 259). They may be either positive (e.g., feeling of joy) or negative (e.g., feeling of panic).

Hannula (2011) developed a theoretical framework related to emotional atmosphere in the classroom (Table 1), which can be regarded from a psychological and social point of view. The psychological dimension refers to the level of an individual and involves affective conditions (emotions, thoughts, meanings and goals), and affective properties (attitudes, beliefs, values and motivational orientations). The social dimension refers to the classroom community. Its affective conditions refer to social interaction, communication and the atmosphere in a classroom, while affective properties refer to norms, social structures and the atmosphere in the classroom. Another aspect of the framework is the distinction between two temporal aspects of affect: state and traits. State (affective condition) refers to the emotional atmosphere at a specific moment in the classroom, such as different emotions and emotional reactions (e.g., fear and joy), thoughts (e.g., "This is difficult."), meanings (e.g., "I could do it."), and aims (e.g., "I want to solve this task.") (Laine, Näveri, Ahtee, Hannula, \& Pehkonen, 2013). Trait (affective property) refers to more stable conditions or properties, such as attitudes (e.g., "I like maths."), beliefs (e.g., "Maths is difficult."), values (e.g., "Maths is important."), and motivational orientations (e.g., "I want to understand.") (Laine et al., 2013).

Table 1

Hannula's (2011) model of dimensions of the emotional atmosphere in a classroom

\begin{tabular}{lll}
\hline & $\begin{array}{l}\text { Psychological dimension or the } \\
\text { level of the individual }\end{array}$ & $\begin{array}{l}\text { Social dimension or the level of the } \\
\text { community (classroom) }\end{array}$ \\
\hline $\begin{array}{l}\text { Affective condition } \\
\text { (state) }\end{array}$ & $\begin{array}{l}\text { Emotions and emotional reactions } \\
\text { Thoughts } \\
\text { Meanings } \\
\text { Goals }\end{array}$ & $\begin{array}{l}\text { Social interaction } \\
\text { Communication } \\
\text { Atmosphere in the classroom } \\
\text { (momentarily) }\end{array}$ \\
\hline $\begin{array}{l}\text { Affective property } \\
\text { (trait) }\end{array}$ & $\begin{array}{l}\text { Attitudes } \\
\text { Beliefs } \\
\text { Values } \\
\text { Motivational orientations }\end{array}$ & $\begin{array}{l}\text { Norms } \\
\text { Social structures } \\
\end{array}$ \\
\hline
\end{tabular}


Attitudes and beliefs about mathematics and mathematics education have been explored more than mathematics-related emotions (e.g., Hannula, 2011), but the focus has largely been on the teacher, and not on students (Philipp, 2007). Research on the affective domain with young students has predominantly used standard methods, such as questionnaires and interviews (e.g., Carmichael, Callingham, \& Watt, 2017). Recently, however, other methods have been employed, such as using participants' drawings, especially in research on young students' beliefs and affect (Laine et al., 2013; Rolka \& Halverscheid, 2006, 2011).

\section{Visual representations of students' beliefs and emotional atmosphere}

Dörfler (2006) highlights the importance of visual representations for the development of cognitive processes in primary school mathematics. Visual representations encompass the construction of internal and external images. External representations refer to pictures, diagrams or graphs, and can lead to knowledge and skills that cannot be achieved by internal representations (Zhang, 1997). Drawings have been recognised as an alternative method to help researchers access children's lived experiences (Anning \& Ring, 2004; Einarsdóttir, 2007) and to gain insights into a multi-dimensional view of their beliefs and latent emotional experiences.

In the last decade, researchers (e.g., Halverscheid \& Rolka, 2006; Laine et al., 2013, 2015; Rolka \& Halverscheid, 2006, 2011) have successfully used drawings to access students' beliefs and emotions about mathematics and mathematics education. For instance, Laine et al. $(2013,2015)$ used students' drawings to examine what kind of general emotional atmosphere dominates in grade 3 and grade 5 mathematics lessons in Finland. The results showed mainly a positive emotional atmosphere in third-grade mathematics classrooms, while fifth-graders illustrated both a positive and negative mood in most of the drawings. Moreover, the authors found that the emotional atmosphere differed greatly between different classes. On the other hand, Pehkonen, Ahtee and Laine (2016) focused on different forms of communication in grade 3 mathematics lessons, specifically addressing the teacher's communication with students, and communication between students within class, as presented in students' drawings. The authors concluded that students' drawings presented teachers as the main deliverers of mathematical knowledge. These studies demonstrated the utility of using drawings as external representation to study the emotional atmosphere in mathematics lessons. However, they focused on mathematics in general, and not on specific mathematical content, such as geometry, which is traditionally an important part of mathematics education. 


\section{Research questions}

In order to gain insights into young students' individual conceptions of geometry, and how geometry is taught with respect to both the level of the individual and the community, viable and age-appropriate methods are paramount. As outlined earlier, many studies (e.g., Laine et al., 2013, 2015; Pehkonen et al., 2011, 2016; Rolka \& Halverscheid, 2011) have shown that the use of drawings allows children, in a unique and innovative manner, to better recall and express in more detail events and phenomena in a holistic way. With these goals in mind, the present study focused on drawings as external representations of four children's fundamental mathematical ideas and the emotional atmosphere in geometry lessons. The following research questions guided the study:

What fundamental ideas of geometry do primary grade students hold on the basis of their drawings?

What emotional and social elements of classroom climate do primary grade students report on through their drawings?

\section{Methods}

\section{Research design and subjects}

A multiple case study qualitative research design was chosen for the study, with "the intention to better understand intrinsic aspects of the particular [participant or group]" (Berg, 2007, p. 291). A case study allows one to answer questions such as how and why the specific phenomenon occurred, thus pushing the study beyond description alone and explaining the phenomenon in depth, in a real context and holistically (Patton, 2002). The study participants were four high-achieving students of grades 2 to 5 from the Zagreb area (Croatia): Gavin (male, $2^{\text {nd }}$ grade drawing), Helen (female, $3^{\text {rd }}$ grade drawing), Marvin (male, $4^{\text {th }}$ grade drawing) and Leoni (female, $5^{\text {th }}$ grade drawing). This age group was optimal for the purposes of the study, as it is an important period for the development of geometric thinking. We took one student drawing per grade level, because the intention was to collect rich and in-depth data on the fundamental geometric ideas of four primary grade students using individual representations, and to compare them with the requirements of the planned curriculum of the particular grade. In addition, we selected drawings of highachieving mathematics students, because their drawings were rich in both geometrical content as well as classroom climate elements. 


\section{Data collection instruments}

The research data consisted of (1) audio data, (2) document review, and (3) a semi-structured interview. The audio data were comprised of the students' unprompted verbal reports during the drawing process, and prompted verbal reports after the drawing process. For the document review, two different instruments were used, adapted from the work of Rolka and Halverscheid (2006, 2011), Halverscheid and Rolka (2006), Laine et al. (2013, 2015) and Pehkonen et al. (2011). They involved drawing the fundamental ideas of geometry (instrument 1), and drawing the geometry classroom (instrument 2). In the first instrument, the students were given a piece of paper with the following assignment: "Imagine you are an artist. A good friend asks you what geometry is. Draw a picture in which you explain to him/her what geometry is for you. Be creative in your ideas." In addition, the students answered the following three questions:

- In what way is geometry present in your drawing?

- Why did you choose these elements in your drawing? Why did you choose this kind of representation?

- Is there anything you didn’t draw but still want to say about geometry?

Based on the age of the student, these questions were answered either orally or in written form. When answers were given orally, the students were audio-taped, otherwise the students wrote their answers (2).

The second instrument was embedded in a so-called Anna-letter (Dohrmann \& Kuzle, 2014) as a source of data regarding the emotional atmosphere in a geometry lesson. In this data source, a bright new girl called Anna enters the participant's school. When she is introduced, the students are asked to draw her two pictures of their mathematics lessons (a lesson in arithmetic and a lesson in geometry) in order to feel more welcome in the new class. In the semi-structured interview, (3) the students were asked to describe what they had drawn, the general atmosphere in the classroom, their own and their peers' emotions, and the mood of the teacher. Multiple data sources were used to assess the consistency of the results, and to increase the validity of the instruments.

\section{Procedure and data analysis}

The research data were collected in a one-to-one setting between the student (Gavin, Marvin, Leoni) and the researchers, and between a preservice 
teacher ${ }^{4}$ and the student (Helen). Gavin, Marvin and Leoni were in the first semester, while Helen was in the second semester of the school year. It was briefly explained to each student that we were interested in geometry, and that they were to produce different drawings during the session. After the student had completed each drawing, the semi-structured interview commenced.

The drawings were analysed after all of the data had been collected. The analysis of the drawings is understood as interpreting the meanings that the students had given to the situations and objects they had presented. These meanings influence the students' actions (Blumer, 1986) and what they draw. As suggested by Patton (2002), multiple stages of the analysis - the withincase analysis and the cross-case analysis - were conducted using an analytic approach. For the within-case analysis, each case (student) was treated as a comprehensive case, whereas the cross-analysis was used to compare the particular cases against each other.

In the first step, the audio data were transcribed after each session. Analysis of the first instrument was then undertaken in order to answer the first research question. The analysis contained the following steps: (1) analysis of drawings with respect to the framework of Wittmann (1999), (2) confirmation of the interpretation by content analysis of the three questions, (3) coding of other conceptions included in the students' oral/written data. The different representations of the fundamental ideas of geometry were first assigned one of Wittmann's (1999) categories (see Table 2) and then assigned a specific subcategory. If a descriptor was not given, both researchers discussed the nature of the fundamental idea before developing a new subcode, thus extending the coding manual. The same procedure was used with all four cases. Both researchers analysed the drawings separately using the coding manual for the analysis of the students' fundamental ideas in geometry, followed by a discussion of the results. The interrater reliability was high (89 percent agreement). Adjustments were subsequently made to the coding manual and our coding, after which the interrater reliability was 100 percent.

4 The preservice teacher was instructed on how to conduct the study with one female student. 
Table 2

Coding manual for the analysis of the students' fundamental ideas in geometry

\begin{tabular}{|c|c|c|}
\hline Fundamental ideas & Description & Examples \\
\hline $\begin{array}{l}\text { Geometric forms } \\
\text { and their construc- } \\
\text { tion }\end{array}$ & $\begin{array}{l}\text { Geometric forms are represented and their } \\
\text { properties are described. } \\
\text { Drawing as an activity or drawing tools are } \\
\text { present in the drawing. }\end{array}$ & $\begin{array}{l}\text { The student draws dif- } \\
\text { ferent 2-dim. geometric } \\
\text { forms. }\end{array}$ \\
\hline $\begin{array}{l}\text { Operations with } \\
\text { forms }\end{array}$ & $\begin{array}{l}\text { Geometric mappings (e.g., translation, } \\
\text { rotation, dilation, congruency), symmetric } \\
\text { figures, composing and decomposing and } \\
\text { attaining composed figures fall into this } \\
\text { category. }\end{array}$ & $\begin{array}{l}\text { The student draws a figure } \\
\text { that is symmetric to the } \\
\text { original geometric form. }\end{array}$ \\
\hline Coordinates & $\begin{array}{l}\text { Geometric forms are placed in a coordinate } \\
\text { system. Positional relationships (in the place } \\
\text { or space) and spatial visualisation also fall } \\
\text { into this category. }\end{array}$ & $\begin{array}{l}\text { The student draws a coor- } \\
\text { dinate system. }\end{array}$ \\
\hline Measurement & $\begin{array}{l}\text { Geometric forms are described on the basis } \\
\text { of their measurements, such as length, } \\
\text { perimeter, area, volume and angle size. Unit } \\
\text { conversion also falls into this category. }\end{array}$ & $\begin{array}{l}\text { The student writes a } \\
\text { formula for the perimeter } \\
\text { of a square. }\end{array}$ \\
\hline Geometric patterns & Geometric patterns fall into this category. & $\begin{array}{l}\text { The student draws a frieze } \\
\text { pattern. }\end{array}$ \\
\hline $\begin{array}{l}\text { Forms in the envi- } \\
\text { ronment }\end{array}$ & $\begin{array}{l}\text { Geometric forms are used to describe the } \\
\text { world around us. }\end{array}$ & $\begin{array}{l}\text { The student draws a robot } \\
\text { made out basic elemen- } \\
\text { tary forms. }\end{array}$ \\
\hline Geometrisation & $\begin{array}{l}\text { Geometry is used as a language to describe } \\
\text { geometric properties, facts and problems. }\end{array}$ & $\begin{array}{l}\text { The student draws a paral- } \\
\text { lel projection of a cube. }\end{array}$ \\
\hline
\end{tabular}

The analysis of the second instrument then commenced in order to answer the second research question. The analysis involved the following steps: (1) analysis of affective conditions on the level of the individual with respect to the framework of Laine et al. (2015), (2) confirmation of the interpretation by content analysis of the semi-structured interview, (3) analysis of the affective conditions on the level of the community with respect to the framework of Pehkonen et al. (2016), (4) confirmation of the interpretation by content analysis of the semi-structured interview, and (5) extending the coding manual on the basis of additional social elements included in the students' drawings and in the interview data. The emotions or thoughts of each student represented in the drawing were assigned one of the subcategory codes before assigning a code for the drawing as a whole, as given in Table 3. The same procedure was used for all four cases. As with the first instrument, both researchers analysed the drawings separately using the coding manual for the analysis of affective conditions pertaining to psychological and social dimensions during a geometry lessons. 
Afterwards, we discussed our coding results with respect to affective conditions on the level of the individual. The interrater reliability was high (10o percent agreement). The drawings were then analysed with respect to affective conditions on the level of the community, as suggested by Pehkonen et al. (2016) (see also Table 3). If a descriptor was not given, both researchers discussed the nature of the communication before developing a new subcode, thus extending the coding manual. After all of the data were coded, both researchers discussed the coding results. The interrater reliability was high (10o percent agreement).

Table 3

Coding manual for the analysis of affective conditions pertaining to psychological and social dimensions

\begin{tabular}{|c|c|c|}
\hline Component & Subcomponent & Descriptor \\
\hline \multirow[t]{5}{*}{$\begin{array}{l}\text { Psychological } \\
\text { dimension }\end{array}$} & positive & $\begin{array}{l}\text { Persons smile and/or think positively, although some of the } \\
\text { expressions can be neutral. }\end{array}$ \\
\hline & ambivalent & $\begin{array}{l}\text { There are both positive and negative facial expressions or } \\
\text { thoughts in the drawing. }\end{array}$ \\
\hline & negative & $\begin{array}{l}\text { Persons are sad or angry or think negatively, although some } \\
\text { of the expressions can be neutral. }\end{array}$ \\
\hline & neutral & All facial expressions and/or other thoughts are neutral. \\
\hline & unidentifiable & $\begin{array}{l}\text { No facial expressions and/or thoughts are present in the } \\
\text { drawing. }\end{array}$ \\
\hline \multirow[t]{2}{*}{$\begin{array}{l}\text { Social } \\
\text { dimension }\end{array}$} & $\begin{array}{l}\text { Teacher's } \\
\text { communication }\end{array}$ & $\begin{array}{l}\text { Teacher: } \\
\text { poses questions; } \\
\text { gives task; } \\
\text { gives instructions; } \\
\text { teaches; } \\
\text { gives feedback; } \\
\text { maintains order; } \\
\text { quietly observes pupils' working }\end{array}$ \\
\hline & $\begin{array}{l}\text { Students' } \\
\text { communication }\end{array}$ & $\begin{array}{l}\text { Student: } \\
\text { answers the teacher's question; } \\
\text { makes/asks/thinks a remark/question in connection to } \\
\text { teaching; } \\
\text { solves a task; } \\
\text { asks for help; } \\
\text { discusses something with other student(s); } \\
\text { makes/thinks an improper remark; } \\
\text { keeps order; } \\
\text { works quietly without communicating with other students }\end{array}$ \\
\hline
\end{tabular}




\section{Results}

Here we present the within-case analysis by treating each student as a comprehensive case giving a holistic perspective on geometry as seen in the students' drawings. The cases are organised on the basis of the grade level.

\section{Gavin $\left(2^{\text {nd }}\right.$ grade drawing $)$}

In Gavin's session, three fundamental ideas arose: geometric forms and their construction, measurement and geometrisation. The first fundamental idea was visualised in the drawing, as shown in Figure 1, with many different subcomponents:

- $\quad$-dim. forms: point as end points of a line segment and as intersection of line segments;

- 1-dim. forms: straight line segment, curved line segment, broken line segment;

- 2-dim. forms: rectangle, triangle, square, circle disc;

- 3-dim. forms: rectangular prism, sphere, cylinder, cone, pyramid, cube; and

- $\quad$ geometric properties: 2-dim. forms as constituent parts of 3-dim. forms (e.g., rectangle as a side of a rectangular prism); point belonging and not belonging to a straight segment.

The fundamental ideas of measurement and geometrisation were mentioned in the interview. With respect to measurement, Gavin described that, in geometry, the lengths of line segments can be measured with a meter as the measurement unit. He added that, for him, measurement is also geometry, but he did not know how to draw it. Lastly, the aspect of geometrisation arose when he was asked whether there was anything he had not drawn but still wanted to say about geometry. He then described a game in which streets are built with straight and curved line segments, and are used to transport different vehicles (e.g., motorcycle, truck). During the game, a problem arose to add line segments of different length to build a bridge so that the vehicles could be transported. He described how he solved the problem using the language of geometry, thus translating the result into the language of the game.

The mode of the emotional atmosphere in the lesson from a psychological point of view is positive (see Figure 1). Both students have positive facial expressions, while the teacher's facial expression is neutral with positive feedback. The drawer ("JA") has a smiling facial expression. The second student is raising her hand to show the teacher she is willing to answer the question presented on the blackboard. The teacher gives positive feedback and the student smiles. 


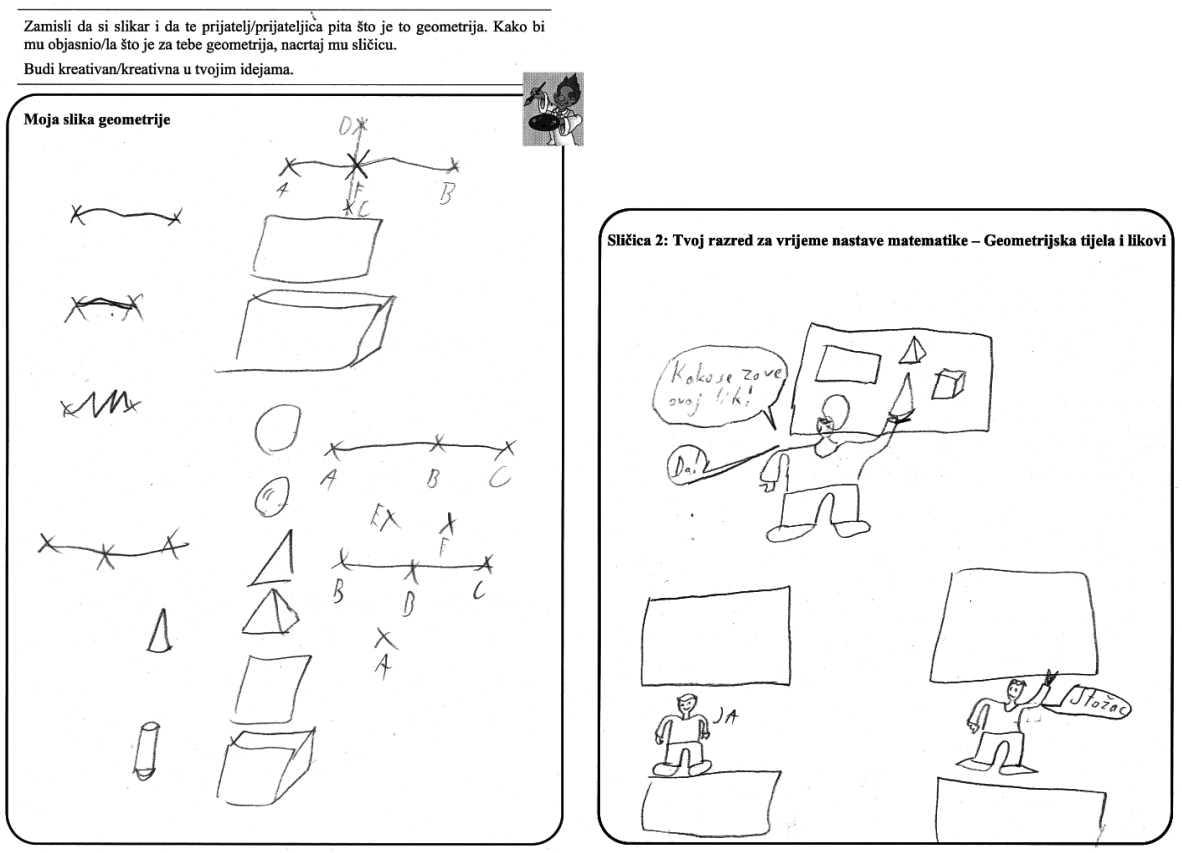

Figure 1. Gavin's drawing of geometry and the emotional atmosphere in a geometry lesson.

The emotional atmosphere in the drawing from a social point of view entails both elements of teacher and student communication, as shown in Figure 1. The teacher stands in the front of the classroom with forms and shapes drawn on the blackboard posing a question related to a drawn geometric shape. A student answers the teacher's question and the teacher gives the student positive feedback by saying "Yes!". In the semi-structured interview, Gavin added that this type of communication occurred often.

\section{Helen ( $3^{\text {rd }}$ grade drawing)}

Helen emphasised two fundamental ideas in her illustration: geometric forms and their construction, and operations with forms. She presented the following geometric forms, as shown in Figure 2:

- $\quad$-dim. forms: point as the intersection of lines and as end points of a line segment;

- 1-dim. forms: straight, curved and broken lines, pencil of lines;

- 2-dim. forms: triangle, square, circle disc;

- 3-dim. forms: pyramid; and

- constructing geometric forms using basic geometric forms: a 2-dim. 
form composed of a square and two triangles was constructed - two triangles were constructed on two opposite square sides.

With respect to the fundamental idea of operations with forms, the aspect of mirror symmetry arose. Unlike other participants, Helen placed the geometric objects in the picture in a special way so that they were distributed symmetrically (Figure 2). Therefore, geometry for her is not just drawing numerous geometrical objects, but also their mutual position on a plane/in space. This result could not be obtained through an interview alone; it was necessary to include a visual method, such as drawing.

The mode of the emotional atmosphere in the presented geometry lesson from a psychological point of view is positive. Since all of the characters are drawn from their back, the facial and mouth expressions are unidentifiable. Nonetheless, the interview and the speech bubbles in the drawing reveal that the teacher and two of the students are in a good mood. These students are interested in what the teacher is saying; they raise their hands because they have questions for the teacher. The third student remarks that he is bored, while the fourth student hushes him because he wants to listen to the lesson.

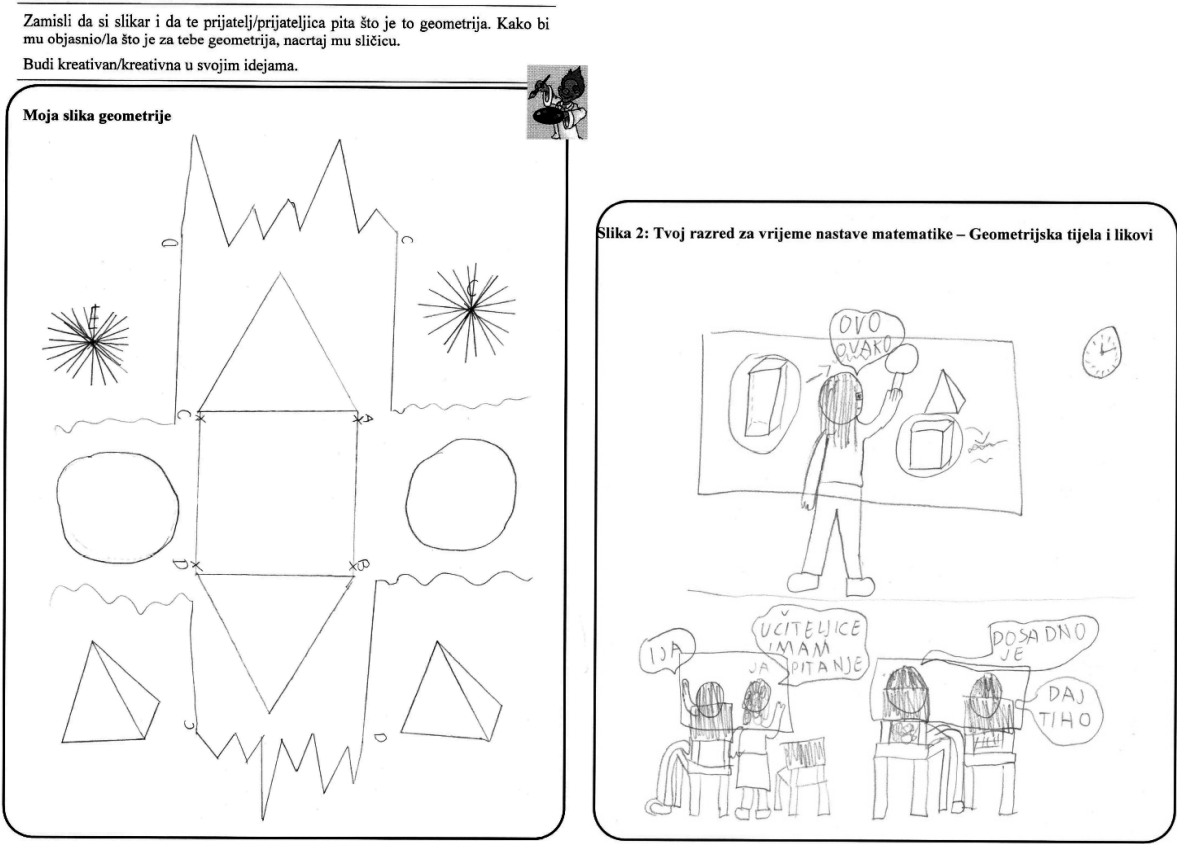

Figure 2. Helen's drawing of geometry and the emotional atmosphere in a geometry lesson. 
With respect to the emotional atmosphere from a social point of view, the central character is the teacher, who frontally gives instructions to the class on how to draw a geometric shape. The teacher is facing the blackboard and communicates with the students with her back to the class. When asked in the interview about what the teacher is doing, Helen answered "Well, she is just drawing there". All of the students are paying attention to the teacher's actions and reacting to them.

\section{Marvin ( $4^{\text {th }}$ grade drawing)}

In Marvin's session, three fundamental ideas arose: geometric forms and their construction, measurement, and forms in the environment. All three fundamental ideas are visualised in the drawing (Figure 3). The following ideas pertaining to geometric forms and their construction are present:

- 1-dim. forms: straight line segment, line, circle;

- 2-dim. forms: square, rectangle, rhombus, triangle, parallelogram, circle disc;

- 3-dim. forms: cube, rectangular prism, pyramid, cylinder, cone, sphere;

- $\quad$ geometric properties: parallel lines, orthogonal lines; and

- drawing/construction tools: construction of a segment using a compass.

With respect to the fundamental idea of measurement, different aspects were also represented:

- length: length of 50 is assigned to the radius of a circle;

- $\quad$ perimeter: written as a word;

- $\quad$ area: written as a word; and

- volume: written as a word.

Marvin remarked that he did not know how to draw some measurements (perimeter, area, volume), so he wrote them in words. Moreover, he added that unit conversion (e.g., from $\mathrm{mm}$ to $\mathrm{cm}$ ) also falls into geometry. Finally, his drawing reveals another fundamental idea: forms in the environment. He drew a globe as real life representative of a sphere. 


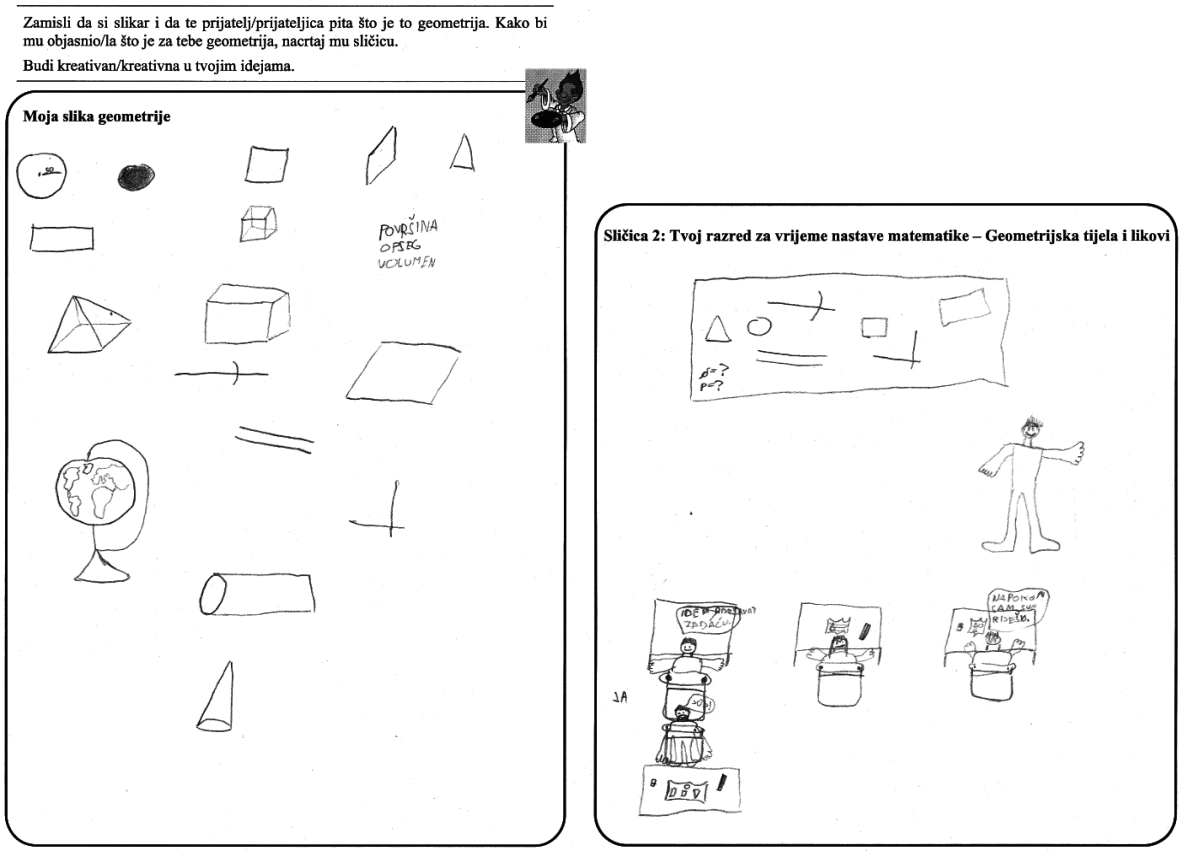

Figure 3. Marvin's drawing of geometry and the emotional atmosphere in a geometry lesson.

The mode of the emotional atmosphere in his geometry lesson from a psychological point of view is ambivalent. There are both positive and negative facial expressions and thoughts in the drawing (Figure 3). The teacher has a smiling facial expression. The drawer ("JA") has a smiling facial expression as he has solved the task given by the teacher and goes on to solving the homework. Furthermore, the open arms give the impression of positive body language. The girl next to him is angry, as her construction of a rectangle is not precise. The student on the right hand side smiles, as he knew how to solve the task ("I finally solved it all"). The student in the bottom has a negative thought "Oh no" ("Joj") because he does not how to solve the task. In addition, the position of the arms, which are hanging, indicates negative body language. These emotions and emotional reactions were confirmed in the interview.

The emotional atmosphere from a social point of view entails both elements of teacher and student communication, as shown in Figure 3. The teacher is standing in front of the classroom and assigning tasks, which are presented on the blackboard. The students are individually solving the problems, while the teacher quietly observes them. In addition, three students are making or thinking a remark related to teaching. 


\section{Leoni $\left(5^{\text {th }}\right.$ grade drawing)}

In Leoni's drawing, two fundamental ideas arose: geometric forms and their construction, and measurement (Figure 4). The following ideas pertaining to geometric forms and their construction are present in her drawing:

- 1-dim. forms: circle;

- 2-dim. forms: triangle, square, circle disc;

- 3-dim. forms: cube; and

- $\quad$ geometric properties: the square is a face of a cube, the circle bounds the circle disc.

With respect to the fundamental idea of measurement, Leoni presented the side length of a triangle. In the interview, she added that, for her, geometry also means measuring areas, but she did not know how to draw that in the picture.

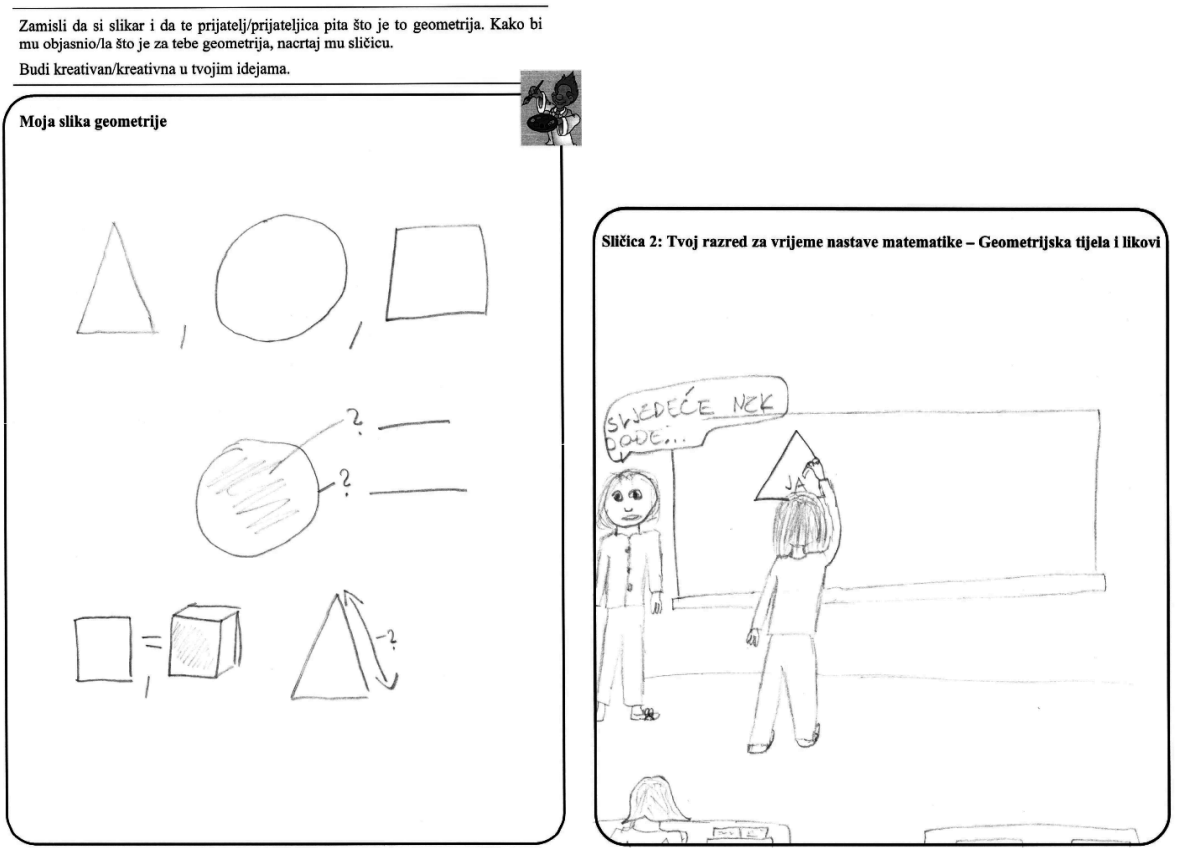

Figure 4. Leoni's drawing of geometry and the emotional atmosphere in a geometry lesson.

The mode of the emotional atmosphere in the presented geometry lesson from a psychological point of view is unidentifiable. The drawing contains 
three characters: a teacher and two students. Both students are drawn from their back without speech or thought bubbles, while the teacher has a neutral facial expression.

Regarding the emotional atmosphere from a social point of view, the teacher is standing in the front of the classroom, while a student (Leoni, "JA") is finishing drawing a triangle on the blackboard. In the interview, Leoni added that the teacher first assigns the task, and the students solve it quietly in their notebooks. Then, after a couple of minutes, the teacher calls a student to solve the task on the blackboard, which then serves as feedback for the other students. Then the next task is given. This explanation can be observed in the drawing. Therefore, the communication in the classroom includes the teacher giving instructions and assigning tasks, and the students solving the given tasks and working quietly without communicating with the other students.

\section{Discussion and Conclusions}

Geometry has traditionally been assigned an important role in school mathematics. The global problem of the reduction of geometry in school mathematics curricula, however, raises the question as to how geometry is taught nowadays and what exactly is covered. This issue refers to a complex construct containing various dimensions, such as students' fundamental ideas about geometry, the nature of geometry education, the social and affective domain, etc. The multiple case study presented in this paper used drawings as external representations of students' conceptions of geometry and the emotional atmosphere on the level of the individual and of the community in geometry lessons.

\section{Students' conceptions of geometry}

The multiple case study results show that the four primary grade students presented a rather narrow conception of geometry, mostly depicting the fundamental idea of geometric forms and their construction (Wittmann, 1999). The participants most often represented points, line segments, lines, plane shapes and common $3 \mathrm{D}$ shapes. The square, the triangle and the circle disc were presented in all four drawings as the strongest representatives of what geometry is for the students. Three of the participants also illustrated several properties of geometric objects. The focus on geometric forms and their construction in the participants' drawings is not surprising, as this fundamental idea dominates the Croatian mathematics curriculum (MZOS, 2006). In three of the examined cases, the idea of measurement was also associated with the participant's 
view of geometry. This idea was difficult for the participants to draw; instead, concepts pertaining to measurement were presented in the picture as words or were added in the interview. These ideas involved the length of a segment, perimeter, area and volume, which are in line with the grade level of the particular student (MZOS, 2006). The idea of geometric mappings (specifically, mirror symmetry) was used by only one of the participants. Interestingly, this idea is not part of the primary education curriculum in Croatia (MZOS, 2006). While the Croatian curriculum emphasises the general idea of using school geometry in everyday life (MZOS, 2006), the idea of geometric forms in the environment was only illustrated by Marvin. Fundamental ideas about geometric patterns and coordinates were absent in all four students' drawings, nor were they mentioned in the interviews. The interview with Gavin revealed the existence of geometrisation, i.e., using the language of geometry and translating it into the language of a children's building game.

The results show that the participants' individual conceptions of geometry are aligned with the recommendations of the current Croatian curriculum (MZOS, 2006), where the emphasis is placed on geometric objects and their construction and properties, while patterns, positional relationships, spatial visualisations and geometrisation are less represented or not present at all. However, geometric forms are just one dimension of the process of understanding geometry, and its sole focus may result in individual students developing a narrow view of geometry.

\section{The emotional atmosphere in geometry lessons}

On the basis of the four cases, the analysis of the emotional atmosphere in geometry lessons on the level of the individual could be described as positive, unidentifiable or ambivalent, but in no case dominantly negative. These findings are in line with the results presented in Laine et al. (2013, 2015). In two cases, facial expression and speech bubbles helped interpret the student drawings, which were confirmed through the semi-structured interview. With respect to the social aspect (i.e., social interaction, communication), the participants presented their typical geometry lessons, with the teacher dominating in front of the blackboard and the students sitting in their seats and working individually in all four cases. These findings are in line with Pehkonen et al. (2016), where, in their illustrations of mathematics lessons, a significant proportion of students drew expository teaching and the teacher posing questions. Despite the frontal teaching, the social aspects in the four drawings differ: in Gavin's picture, the teacher is addressing the students asking the names of geometric 
shapes, and gives feedback when a student answers correctly; in Helen's drawing, the teacher is giving instruction facing the blackboard, while the students would like to participate with questions or are bored; in Marvin's picture, the teacher is quietly observing as the students solve problems individually; in Leoni's picture, the teacher is giving instructions and assigning tasks, while the students solve tasks on the blackboard or work quietly in their seats. In all four of the examined drawings, the students' communication with each other is not present at all or is minimal. The social atmosphere, in which geometry lessons are viewed by individuals as frontal teaching with limited communication between students, is in line with findings regarding mathematics education in Croatia (Glasnović Gracin \& Domović, 2009).

\section{Limitations of the study and future directions}

The present study was a multiple case study. As in all case studies, the goal was not to make generalisations about large populations. We used a small sample of participants, so not every fundamental idea and its constructs were exhibited, nor would it be representative of a large population. Similarly, the results pertaining to the emotional atmosphere are not generalisable. This limitation suggests a possible next step in the research: to conduct a study with a much larger sample in order to obtain a broader picture of students' conceptions of geometry. These insights would enable possible practical contributions by providing teachers with ideas for modifying their teaching practices to create a more open, encouraging atmosphere in different lessons. Another limitation of the study is the uniqueness of the participants, who were four above-average students. Further research might therefore include interviewing and observing students with different levels of mathematical performance. Furthermore, we reported on emotional atmosphere with respect to a specific mathematical area (geometry), and the results might be limited to the characteristics of this mathematical field. Future research should involve investigating the emotional atmosphere in arithmetic education, as well, because some of the elements found, such as frontal teaching with limited communication, may not be typical just of the individual's view of geometry, but of mathematics education in general.

Even though the students' drawings opened a new way to evaluate and observe classroom communication, the possible limitations of using drawings as a data-gathering method have been discussed in the literature (e.g., Einarsdóttir, 2007; Pehkonen et al., 2011). It is important to consider that some children have difficulties drawing, some do not like to draw, some predominantly draw the objects that they find easy to illustrate, and some might imitate the 
drawings of their colleagues. The research presented in this paper reveals that there are some issues related to geometry that are not easy to draw, such as measurements and geometrisation. In addition, in all of the participants' drawings, the teacher was standing in front of the blackboard, so it was not always possible to see all of the characters' mouth or facial expressions, because they were drawn from the back. Therefore, it is important to triangulate this research method (e.g., using interviews).

Understanding students' conceptions of geometry and the emotional atmosphere in geometry lessons is an issue of concern and remains an ongoing research area. In this regard, alternative research methods, such as drawings, provide a holistic understanding of this multifaceted phenomena. Further studies on these issues are vital, and the search for alternative instruments with these goals in mind, especially in the context of primary grade students, continues.

\section{References}

Anning, A., \& Ring, K. (2004). Making sense of children's drawings. Maidenhead, UK: Open University Press.

Berg, B. L. (2007). Qualitative research methods for the social sciences (6th ed.). Boston, MA: Pearson. Blumer, H. (1986). Symbolic interactionism. Perspective and method. Berkeley, CA: University of California Press.

Carmichael, C., Callingham, R., \& Watt, H. (2017). Classroom motivational environment influences on emotional and cognitive dimensions of student interest in mathematics. ZDM Mathematics Education, 49(3), 449-460.

Dörfler, W. (2006). Diagramme und Mathematikunterricht [Diagrams and mathematics teaching]. Journal für Mathematik-Didaktik, 27(3/4), 200-219.

Dohrmann, C., \& Kuzle, A. (2014). Unpacking children's angle "Grundvorstellungen": The case of distance Grundvorstellung of $1^{\circ}$ angle. In P. Liljedahl, C. Nicol, S. Oesterkle, \& D. Allan (Eds.), Proceedings of the 38 th conference of the international group for the psychology of mathematics education and the 36 th conference of the north American chapter of the psychology of mathematics education (Vol. 2, pp. 409-416). Vancouver: PME.

Einarsdóttir, J. (2007). Research with children: Methodological and ethical challenges. European Early Childhood Education Research Journal, 15(2), 197-211.

Glasnović Gracin, D., \& Domović, V. (2009). Upotreba matematičkih udžbenika u nastavi viših razreda osnovne škole [Using mathematics textbooks in lower secondary education]. Odgojne znanosti, 11(2), 297-317.

Halverscheid, S., \& Rolka, K. (2006). Student beliefs about mathematics encoded in pictures and words. In J. Novotná, H. Moraová, M. Krátká, \& N. Stehlíková (Eds.), Proceedings of the zoth conference of the international group for the psychology of mathematics education (Vol. 3, pp. 233-240). Prague: PME. 
Hannula, M. S. (2011). The structure and dynamics of affect in mathematical thinking and learning. In M. Pytlak, E. Swoboda, \& T. Rowland (Eds.), Proceedings of the seventh congress of the European society for research in mathematics education (pp. 34-6o). Poland: University of Rzesów.

Jones, K. (2000). Critical issues in the design of the geometry curriculum. In B. Barton (Ed.), Readings in mathematics education (pp. 75-90). Auckland: University of Auckland.

Laine, A., Näveri, L., Ahtee, M., Hannula, M. S., \& Pehkonen, E. (2013). Emotional atmosphere in third-graders' mathematics classroom - an analysis of pupils' drawings. Nordic Studies in Mathematics Education, 17(3-4), 101-116.

Laine, A., Ahtee, M., Näveri, L., Pehkonen, E., Portaankorva-Koivisto, P., \& Tuohilampi, L. (2015). Collective emotional atmosphere in mathematics lessons based on Finnish fifth graders' drawings. LUMAT - Research and Practice in Math, Science and Technology Education, 3(1), 87-100.

Mammana, C., \& Villani, V. (1998). Perspectives on the teaching of geometry for the 21st century: An ICMI study. Dordrecht: Kluwer.

MZOS [Ministry of Science, Education and Sports] (2006). Nastavni plan i program za osnovnu školu [The educational plan and programme for elementary school]. Zagreb: Ministry of Science, Education and Sports.

Patton, M. Q. (2002). Qualitative research and evaluation methods. Thousand Oaks, CA: Sage.

Pehkonen, E., Ahtee, M., Tikkanen, P., \& Laine, A. (2011). Pupils' conception on mathematics lessons revealed via their drawings. In B. Roesken \& M. Casper (Eds.), Proceedings of the MAVI-17 conference (pp. 182-191). Bochum: Ruhr-Universität Bochum.

Pehkonen, E., Ahtee, M., \& Laine, A. (2016). Pupils' drawings as a research tool in mathematical problem-solving lessons. In P. Felmer, E. Pehkonen, \& J. Kilpatrick (Eds.), Posing and solving mathematical problems. Advances and new perspectives (pp. 167-188). New York, NY: Springer.

Philipp, R. A. (2007). Mathematics teachers' beliefs and affect. In F. K. Lester (Ed.), Second handbook of research on mathematics teaching and learning (Vol. 2, pp. 257-315). Charlotte, NC: Information Age. Rolka, K., \& Halverscheid, S. (2006). Pictures as a means for investigating mathematical beliefs. In S. Alatorre, J. L. Cortina, M. Sáiz, \& A. Méndez (Eds.), Proceedings of the 28 th annual meeting of the North American chapter of the international group for the psychology of mathematics education. Mérida: Universidad Pedagógica Nacional.

Rolka, K., \& Halverscheid, S. (2011). Researching young students' mathematical world views. ZDM Mathematics Education, 43(4), 521-533.

Winter, H. (1976). Was soll Geometrie in der Grundschule [What should geometry be like in elementary school?]. Zentralblatt Didaktik der Mathematik, 8, 14-18.

Wittmann, E. Ch. (1999). Konstruktion eines Geometriecurriculums ausgehend von Grundideen der Elementargeometrie [The construction of a geometry curriculum based on the fundamental ideas of elementary geometry]. In H. Henning (Ed.), Mathematik lernen durch Handeln und Erfahrung. Festschrift zum 75. Geburtstag von Heinrich Besuden (pp. 205-223). Oldenburg: Bueltmann und Gerriets. Zhang, J. (1997). The nature of external representations in problem solving. Cognitive Science, 21(2), $179-217$. 


\section{Biographical note}

Dubravka Glasnović Gracin, $\mathrm{PhD}$, is an assistant professor in primary education in mathematics at the Faculty of Teacher Education, University of Zagreb. Her main fields of interest are: mathematics textbook research (focus: task analysis and development, textbook as a main resource within the resource system), developing and studying mathematics picture books and children's fundamental ideas and social atmosphere in geometry lessons using drawings.

Ana Kuzle, PhD, is an associate professor in primary education in mathematics at the Faculty of Human Sciences, University of Potsdam. Her main fields of interest are: development of teaching quality in primary mathematics teaching and long-term competence development of learners (focus: problem solving, argumentation, metacognition, geometry), implementation of technology in primary school mathematics and children's fundamental ideas and socio-emotional atmosphere in geometry lessons using drawings. 